\title{
ANALYSIS OF POLYMORPHISMS IN THE INTERLEUKIN 18 GENE PROMOTOR (-137 G/C AND -607 C/A) IN PATIENTS INFECTED WITH HEPATITIS C VIRUS FROM THE BRAZILIAN AMAZON
}

\author{
Kemper Nunes dos SANTOS, Marcella Kelly Costa de ALMEIDA, Amanda Alves FECURY, \\ Carlos Araújo da COSTA and Luísa Caricio MARTINS
}

Received 20/2/2015

Accepted 27/4/2015

\begin{abstract}
Background - The hepatitis C virus has been recognized as the leading cause of chronic liver disease in the world. Host genetic factors have been implicated in the persistence of hepatitis $\mathrm{C}$ virus infection. Single nucleotide polymorphisms at positions -607 C/A (rs1946518) and -137 G/C (rs187238) in the IL-18 gene promoter have been suggested to be associated with delayed hepatitis $\mathrm{C}$ virus clearance and persistence of the disease. Objective - Identify these polymorphisms in a population infected with hepatitis C virus from the Brazilian Amazon region. Methods - In a cross-sectional analytical study conducted in Belém, Pará, Brazil, 304 patients infected with hepatitis $\mathrm{C}$ virus were divided into two groups: group $\mathrm{A}$, patients with persistent infection; group B, patients with spontaneous clearance. The control group consisted of 376 volunteers not infected with hepatitis $\mathrm{C}$ virus. Samples were analyzed by RT-PCR for the detection of viral RNA and by RFLP-PCR to evaluate the presence of the -137 G/C and -607 C/A IL-18 gene promoter polymorphisms. Results - Comparison of polymorphism allele frequencies between the patient and control groups showed a higher frequency of allele $\mathrm{C}$ at position -607 among patients $(P=0.02)$. When the association between the polymorphisms and viral infection was analyzed, patients carrying genotype C/A at position -607 were found to be at higher risk of persistent hepatitis $\mathrm{C}$ virus infection $(P=0.03)$. Conclusion - the present results suggest a possible role of the $-607 \mathrm{IL}-18$ gene promoter polymorphism in the pathogenesis of hepatitis $\mathrm{C}$ virus infection.
\end{abstract}

HEADINGS - Single nucleotide polymorphism. Interleukin-18. Hepatitis C. Hepacivirus.

\section{INTRODUCTION}

Since its discovery in 1989, hepatitis C virus (HCV) has been recognized as the leading cause of chronic liver disease in the world. Approximately $3 \%$ of the world population suffers from chronic hepatitis $\mathrm{C}^{(3,22)}$.

Viral replication in the liver for a prolonged period of time can have severe clinical consequences such as fibrosis, cirrhosis, and hepatocellular carcinoma ${ }^{(5,13)}$. Host genetic factors have been implicated in the persistence of HCV infection. In this respect, two polymorphisms in the promoter region of the interleukin 18 (IL-18) gene have been shown to influence the expression of this gene ${ }^{(1)}$.

IL-18, also called interferon gamma (IFN- $\gamma$ ) inducing factor, is a proinflammatory cytokine that plays an important role in both Th1 and Th2 respons$\mathrm{es}^{(13,15)}$. Immune responses and genetic factors are known to influence the prognosis of $\mathrm{HCV}$ infection ${ }^{(8)}$. Cytokines play a critical role in the pathogenesis of $\mathrm{HCV}$ infection, with different clinical outcomes. Evidence indicates that genetic variants of IL-18 can influence host susceptibility, viral persistence or clearance, tissue injury, and the response to antiviral treatment ${ }^{(23)}$. Two single nucleotide polymorphisms (SNP) identified at positions -607 C/A (rs1946518) and $-137 \mathrm{G} / \mathrm{C}$ (rs 187238) in the IL-18 promoter region seem to influence the promoter transcription activity of IL-18 and, potentially, of IFN- $\gamma$, and have been associated with delayed clearance of $\mathrm{HCV}$ and persistence of the disease ${ }^{(1)}$.

To our knowledge, no Brazilian studies have

Declared conflict of interest of all authors: none

Disclosure of funding: no funding received

Laboratório de Patologia Clínica das Doenças Tropicais, do Núcleo de Medicina Tropical, Universidade Federal do Pará, Belém, PA, Brasil.

Correspondence: Luísa Caricio Martins. Núcleo de Medicina Tropical. Av. Generalissimo Deodoro, 92 - Umarizal - CEP: 66000-000 - Belém, PA, Brasil. E-mail: caricio@ufpa.br 
investigated the association between the $-607 \mathrm{C} / \mathrm{A}$ (rs1946518) and -137 G/C (rs187238) SNPs in the IL-18 gene promoter and the outcomes of HCV infection. The objective of the present study was to identify these polymorphisms in a population infected with HCV from the Brazilian Amazon region.

\section{METHODS}

\section{Sample characterization}

A total of 304 patients of Tropical Medicine Center of the viral hepatitis program, were selected and divided into 2 groups: Group A - 174 patients with persistent infection, with anti-HCV and $\mathrm{HCV}$ polymerase chain reaction (PCR) positive for more than 6 months. Group B - 130 patients with spontaneous clearance, characterized by positive anti-HCV and HCV PCR negative. Viral clearance was defined when anti-HCV serology was positive and HCV RNA was undetectable in serum over a period of 6 months or less in the absence of specific HCV treatment (Figure 1). For the control group, 376 anti-HCV-negative volunteers with negative $\mathrm{HCV}$ PCR were selected at random.

None of the patients was co-infected with hepatitis B virus (HBV surface antigen negative) or Human Immunodeficiency Virus (HIV), none of the patients consumed alcoholic beverages, and all were treatment naive. All patients received detailed information about the study and signed a consent form.
All results of serology confirmed by at least these parated serological tests within consecutive 6 months during the follow-up. All subjects were diagnosed by experienced physicians on the basis of clinical and laboratory findings and internationally accepted criteria ${ }^{(18)}$.

All subjects included (patients and control) were of the same socioeconomic status and had similar cultural habits. In addition, all subjects were born in Pará state and had the same ethnic origin, approximately 50\% Portuguese, $40 \%$ Amerindian, and 10\% African ${ }^{(20)}$.

The study was approved by the Ethics Committee of the Tropical Medicine Center, Federal University of Para (Núcleo de Medicina Tropical, Universidade Federal do Pará - NMT/ UFPA), Belém, PA, Brazil (Permit No. 042/2011). All patients gave their informed consent to participate in the study.

\section{Serological testing and HCV genotyping}

Peripheral venous blood $(5 \mathrm{~mL})$ was collected from each participant into EDTA tubes. Plasma was isolated by centrifugation and stored at $-80^{\circ} \mathrm{C}$ until assayed. Serological markers of $\mathrm{HCV}$ infection (anti-HCV antibodies) were investigated using the ETI-ABHCVK-4 kit from Diasorin (Saluggia, Italy).

RNA was extracted from all samples using the QIAamp Viral RNA kit (Hilden, Germany). HCV RNA was investigated by nested PCR using primers that target the 5'-UTR region. The first reaction consisted of the synthesis and amplification of cDNA in a single step using $1 \mathrm{~mL}$ of the $\mathrm{k} 10$

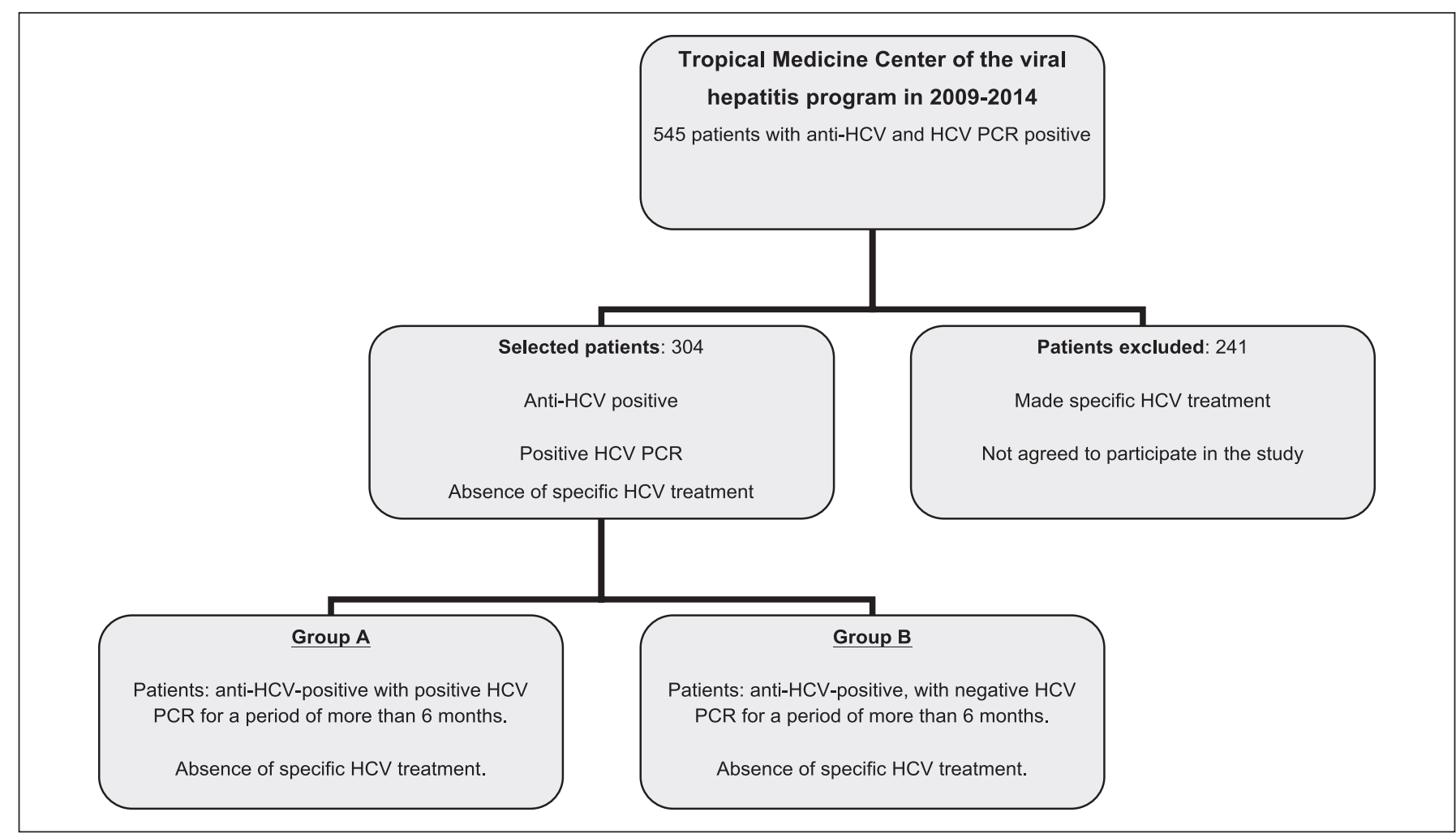

FIGURE 1. Flowchart of inclusion and exclusion criteria of the patients hepatitis $\mathrm{C}$ virus (HCV) carriers participating in the study. 
(5'-GGC GAC ACT CCA CCA TRR-3') and k11 (5'-GGT GCA CGG TCT ACG AGA CC-3') primers, 5 mL DNAsefree ultrapure water, $5 \mathrm{~mL}$ RNAse, and $1 \mathrm{~mL}$ One-Step Taq DNA Polymerase (Invitrogen, São Paulo, Brazil).

The samples were incubated in a thermocycler at $42^{\circ} \mathrm{C}$ for $45 \mathrm{~min}$. The amplification conditions were initial denaturation at $94^{\circ} \mathrm{C}$ for $2 \mathrm{~min}$, followed by 35 cycles of denaturation at $94^{\circ} \mathrm{C}$ for $30 \mathrm{~s}$, annealing at $54^{\circ} \mathrm{C}$ for $30 \mathrm{~s}$, and extension at $72^{\circ} \mathrm{C}$ for $45 \mathrm{~s}$. A final extension was performed at $72^{\circ} \mathrm{C}$ for 7 min and the samples were cooled to $4^{\circ} \mathrm{C}$.

The second reaction mixture contained $2.5 \mathrm{~mL}$ buffer, 4 mL dNTPs, $1.5 \mathrm{~mL} \mathrm{MgCl}, 1 \mathrm{~mL} \mathrm{k15} \mathrm{(5'-ACC} \mathrm{ATR} \mathrm{RAT}$ CAC TCC CCT GT-3') and k16 (5'-CAA GCA CCC TAT CAG GCA GT-3') primers, $12.5 \mathrm{~mL}$ DNAse- and RNAsefree ultrapure water, and $0.5 \mathrm{~mL}$ Platinum Taq DNA Polymerase (Invitrogen).

The virus was genotyped by the restriction fragment length polymorphism (RFLP) technique using Ava II and Rsa I restriction enzymes. Positive and negative controls were included in all reactions ${ }^{(12)}$.

\section{Detection of the IL-18 gene polymorphisms (-137 G/C and $-607 \mathrm{C} / \mathrm{A}$ )}

Human DNA was isolated from whole blood samples (patients and controls) using the PureLink ${ }^{\mathrm{TM}}$ Genomic DNA kit (Invitrogen).

Specific primers were used for the polymorphisms at position -137 G/C: (forward) 5'-TGCTTCTAATGGACTAAGGAGGTG-3' and (reverse) 5'-CTTCTTTTAATGTAATATCACTATTTTCATGAGA-3', and at position -607 C/A: (forward) 5'-TTCTGTTGCAGAAAGTGTAAAAATTTT-3' and (reverse) 5'-AAAGGATAGTTGATACAGGCCATT-3'.

The IL-18 gene polymorphisms were identified as described by An et al. ${ }^{(2)}$. For RFLP-PCR, the restriction enzymes Bgl II and Dra I were used to detect the -137 and -607 polymorphisms, respectively. Digestion with Bgl II produces a single band of $141 \mathrm{bp}$ for allele $\mathrm{C}$ and two bands of 105 and 36 bp for allele $\mathrm{G}$ (Figure 1). Digestion with Dra I produces a single band of $154 \mathrm{bp}$ for allele $\mathrm{C}$ and two bands of 125 and $28 \mathrm{bp}$ for allele $\mathrm{A}$.

\section{Histopathology analysis}

A liver biopsy were obtained from all patients anti-HCV positive. The biopsies were fixed in $10 \%$ buffered formalin, submitted to routine processing, and embedded in paraffin. The paraffin blocks were cut and the sections were stained with hematoxylin-eosin and analyzed by a pathologist.

Fibrosis staging and inflammatory activity grading were used for the classification of chronic hepatitis ${ }^{(23)}$. Fibrosis was staged as follows: 0 : no fibrosis, 1 : portal fibrosis without septa, 2: few septa, 3: numerous septa delineating nodules without cirrhosis, and 4: cirrhosis. Inflammatory activity was graded taking into account activities in the portal tract and in the periportal and lobular regions: 0 : no histological activity, 1: minimal damage, 2: mild activity, 3 : moderate activity and 4 : severe activity.

\section{Statistical analysis}

The results were analyzed using the BioEstat 5.0 program $^{(4)}$. The chi-square test was used to compare frequencies between groups. The frequency distribution of the variables is expressed as percentage and odds ratios (OR) were calculated. A level of significance of $95 \%$ was adopted.

\section{RESULTS}

Table 1 shows the demographic data of each group. No significant difference in mean age or gender distribution was observed between the three groups studied. However, comparison of the frequency of HCV genotypes showed a higher prevalence of genotype 1 in patients with persistent infection (group A) compared to the group with spontaneous clearance (group B).

Histological analysis revealed the presence of chronic hepatitis in all patients. Grade 0 or 1 necroinflammatory activity was observed in $93 \%$ (284/304) of these patients and grade 2 or 3 in 7\% (20/304). Regarding the stage of fibrosis, $90 \%(275 / 304)$ of the patients had stage 0 or 1 and $10 \%$ (29/304) stage 2. Analysis of histopathological alterations between the groups A and B showed no statistically significant difference $(P>0.05)$.

TABLE 1. Demographic and clinical characteristics of HCV-infected patients with persistent infection and spontaneous clearance and controls

\begin{tabular}{lcccc}
\hline & Group A & Group B & Group C & \\
Variable & n(\%) & n (\%) & n (\%) & \\
& 37.5 & 38 & 36 & $0.6251^{\text {a }}$ \\
Mean age (years) & & & & \\
Gender & & & & \\
Male & $120(69)$ & $92(70)$ & $240(64)$ & $0.1561^{\text {b }}$ \\
Female & $54(31)$ & $38(30)$ & $136(36)$ &
\end{tabular}

HCV genotype

$\begin{array}{lllll}1 & 140(80) & 91(70) & - & 0.0481^{c} \\ \text { Non-1 } & 34(20) & 39(30) & - & \end{array}$

Group A: patients with persistent infection; Group B: patients with spontaneous clearance; Group C: control group. a: one-way ANOVA; b: Kruskal-Wallis test; c: $\mathrm{X}^{2}$ test.

\section{Distribution of the IL-18 gene promoter polymor- phisms in patients and controls}

Table 2 shows the genotype frequencies of the $-137 \mathrm{G} / \mathrm{C}$ and $-607 \mathrm{C} / \mathrm{A}$ polymorphisms in the IL-18 gene in patients and in the control group. A higher frequency of genotypes $\mathrm{C} / \mathrm{A}$ and $\mathrm{C} / \mathrm{C}$ of the -607 polymorphism was observed in patients when compared to controls (Table 2). 
TABLE 2. Distribution of the IL-18 gene promoter polymorphisms (-137 G>C, $-607 \mathrm{C}>\mathrm{A})$ in patients and controls

\begin{tabular}{|c|c|c|c|c|c|}
\hline $\mathrm{SNP} /$ genotype & $\begin{array}{c}\text { Patients }(\mathrm{n}=304) \\
\mathrm{n}(\%)\end{array}$ & $\begin{array}{c}\text { Controls }(\mathrm{n}=376) \\
\mathrm{n}(\%)\end{array}$ & OR & $95 \% \mathrm{CI}$ & $P$ \\
\hline \multicolumn{6}{|l|}{$-607 \mathrm{C} / \mathrm{A}$} \\
\hline $\mathrm{A} / \mathrm{A}$ & $36(11.8)$ & $68(18.1)$ & - & - & - \\
\hline $\mathrm{C} / \mathrm{A}$ & $156(51.3)$ & $192(51.1)$ & 1.53 & $0.97-2.42$ & 0.08 \\
\hline $\mathrm{C} / \mathrm{C}$ & $112(36.9)$ & $116(30.8)$ & 1.82 & $1.12-2.94$ & 0.01 \\
\hline $\mathrm{C} / \mathrm{A}+\mathrm{C} / \mathrm{C}$ & 268 & 308 & 1.64 & $1.06-2.54$ & 0.03 \\
\hline A & $228(37.5)$ & $328(43)$ & - & - & - \\
\hline $\mathrm{C}$ & $380(62.5)$ & $424(57)$ & 1.28 & $1.03-1.6$ & 0.02 \\
\hline \multicolumn{6}{|l|}{$-137 \mathrm{G} / \mathrm{C}$} \\
\hline $\mathrm{C} / \mathrm{C}$ & $100(32.9)$ & $128(34)$ & - & - & - \\
\hline $\mathrm{G} / \mathrm{C}$ & $120(39.5)$ & $132(35.1)$ & 1.16 & $0.81-1.66$ & 0.46 \\
\hline G & $288(47.4)$ & $364(48.5)$ & 0.95 & $0.77-1.18$ & 0.74 \\
\hline
\end{tabular}

OR: odds ratio; $95 \% \mathrm{CI}$ : $95 \%$ confidence interval.

\section{Association of IL-18 gene polymorphisms with the resolution of $\mathrm{HCV}$ infection}

To evaluate the influence of the IL-18 gene promoter polymorphisms (-137 G/C and $-607 \mathrm{C} / \mathrm{A})$ on the course of $\mathrm{HCV}$ infection, we compared allele frequencies between the patient groups: group A (persistent infection) and group B (spontaneous clearance). The frequency of allele $\mathrm{C}$ at position -607 was higher in patients with persistent infection than in those with spontaneous clearance (Table 3). No significant difference between patients was observed for the allele distribution at position -137 .

TABLE 3. Association between IL-18 gene polymorphisms and PCR results

\begin{tabular}{lccccc}
\hline $\begin{array}{l}\text { IL-18 } \\
\text { polymorphism }\end{array}$ & $\begin{array}{c}\text { Group A } \\
\text { n (\%) }\end{array}$ & $\begin{array}{c}\text { Group B } \\
\text { n (\%) }\end{array}$ & OR & $95 \%$ CI & $\boldsymbol{P}$ \\
\hline -607 C/A & $\mathrm{n}=174$ & $\mathrm{n}=130$ & & & \\
\hline $\mathrm{A} / \mathrm{A}$ & $14(8)$ & $22(17)$ & - & - & - \\
$\mathrm{C} / \mathrm{A}$ & $96(55)$ & $60(46)$ & 2.51 & $1.19-5.28$ & 0.02 \\
$\mathrm{C} / \mathrm{C}$ & $64(37)$ & $48(37)$ & 2.09 & $0.97-4.51$ & 0.06 \\
$\mathrm{C} / \mathrm{A}+\mathrm{C} / \mathrm{C}$ & 160 & 108 & 2.32 & $1.14-4.70$ & 0.02 \\
\hline$-137 \mathrm{G} / \mathrm{C}$ & $\mathrm{n}=174$ & $\mathrm{n}=130$ & & & \\
\hline $\mathrm{C} / \mathrm{C}$ & $62(35.6)$ & $38(29.2)$ & - & - & - \\
G/C & $64(36.8)$ & $56(43.1)$ & 1.42 & $0.83-2.45$ & 0.24 \\
G/G & $48(27.6)$ & $36(27.7)$ & 1.22 & $0.67-2.21$ & 0.60 \\
G/C+G/G & 112 & 92 & 1.34 & $0.82-2.18$ & 0.29 \\
\hline
\end{tabular}

Group A: patients with persistent infection; Group B: patients with spontaneous clearance. OR: odds ratio; $95 \% \mathrm{CI}: 95 \%$ confidence interval.

\section{DISCUSSION}

Progression of hepatitis $\mathrm{C}$ varies between patients. There is sufficient evidence suggesting that the cause of progression is multifactorial and includes viral, immunological and genetic factors ${ }^{(13)}$.

Among viral factors, the infecting HCV genotype seems to play an important role. In the present study, a higher frequency of genotype 1 was observed in the population studied. In addition, the prevalence of genotype 1 was higher among patients with persistent infection compared to those with spontaneous clearance.

Differences in the distribution of $\mathrm{HCV}$ genotypes between different geographic areas have been demonstrated. In Brazil, genotype 1 is the most frequent, followed by genotypes 3 and $2^{(7)}$. Similar results have been reported for the state of Pará ${ }^{(17,19)}$.

Studies conducted in different countries suggest that the genomic heterogeneity of $\mathrm{HCV}$ has a significant impact on the severity of liver disease and on the response to treatment. In this respect, genotype 1 has been associated with severe liver damage ${ }^{(14,16,21)}$.

Cytokines play a crucial role in the differentiation, maturation and functional activation of immune cells, as well as in the regulation of the immune response that controls the clearance or persistence of $\mathrm{HCV}^{(1,13)}$. The main genes involved in the progression of disease and persistence of $\mathrm{HCV}$ are related to viral replication and to triggering the immune response $^{(13)}$. Host genetic factors have been implicated in the persistence of $\mathrm{HCV}$ infection.

The inflammatory cytokine IL-18 has been indicated as a marker of inflammation and liver damage ${ }^{(6,9)}$. Two SNPs have been described in the promoter region of the IL-18 gene at positions -607 C/A (rs1946518) and -137 G/C (rs187238). 
These polymorphisms are associated with the transcription activity of the IL-18 promoter and cause a reduction in serum IL-18 levels ${ }^{(2,10)}$.

Some research groups suggested that these polymorphisms influence the clinical evolution of $\mathrm{HCV}$ infection. In the present study, comparison of the $-607 \mathrm{C} / \mathrm{A}$ and $-137 \mathrm{G} / \mathrm{C}$ polymorphisms between $\mathrm{HCV}$-infected patients and controls showed a higher frequency of allele $\mathrm{C}$ at position -607 in the patient group. In addition, genotype C/A at position -607 was associated with a higher risk of persistent infection with $\mathrm{HCV}(\mathrm{OR}=2.51)$.

Similar studies conducted in America ${ }^{(1)}$, India ${ }^{(13)}$, and Europe $^{(11)}$ also showed that the mutation from $\mathrm{C}$ to $\mathrm{A}$ at position -607 was associated with viral clearance and protection against severe liver disease in the populations studied.

\section{CONCLUSION}

The importance of -607 and -137 polymorphisms in the IL-18 gene promoter for HCV infection should be further studied, but our studies suggest an association between the polymorphism -607 and the persistence of viral infection.

\section{Authors' contributions}

Santos KN e Almeida MKC: realization of tests for molecular detection of IL-18 polymorphism. Fecury AA: realization of serological and molecular testing for $\mathrm{HCV}$ infection. Costa CA:clinical monitoring of patients. Martins LC: writing and statistical analysis of the article.

Santos KN, Almeida MKC, Fecury AA, Costa CA, Martins LC. Análise do polimorfismo na região promotora do gene da interleucina 18 (-137 G/C e -607 C/A) em pacientes portadores do vírus da hepatite C na Amazônia Brasileira. Arq Gastroenterol. 2015,52(3):222-7.

RESUMO - Contexto - $\mathrm{O}$ vírus da hepatite $\mathrm{C}$ é reconhecido como a maior causa de doença hepática crônica no mundo. Fatores genéticos do hospedeiro têm sido implicados na persistência da infecção pelo vírus da hepatite C. Polimorfismos de nucleotídeos únicos na posição -607 C/A (rs1946518) e -137 G/C (rs187238) na região promotora do gene da IL-18 têm sido evidenciados em alguns estudos que sugerem sua associação ao atraso na depuração do vírus da hepatite $\mathrm{C}$ e na persistência da doença. Objetivo - O presente estudo pretende identificar esses polimorfismos em uma população da região da Amazônia Brasileira infectada pelo vírus da hepatite C. Métodos - Estudo do tipo transversal analítico no município de Belém-PA foi realizado em 304 pacientes infectados pelo vírus da hepatite $\mathrm{C}$, divididos em: grupo A, pacientes com infecção persistente; grupo B, pacientes que apresentaram clareamento viral. Como grupo controle participaram 376 voluntários não infectados pelo vírus da hepatite C. As amostras foram submetidas à RT-PCR, para detecção do RNA viral e, posteriormente, à RFLP-PCR para avaliação do polimorfismo na região promotora do gene da IL-18, nas posições -137 G/C e -607 C/A. Resultados - A comparação das frequências dos polimorfismos no grupo de pacientes com o grupo controle demonstrou uma maior frequência do alelo $C$ na posição - 607 entre os pacientes $(P=0,02)$ que no grupo controle. Na análise da associação dos polimorfismos com a infecção viral foi obtido que portadores do genótipo C/A na posição -607 possuíam maior risco de infecção persistente pelo vírus da hepatite $\mathrm{C}(P=0,03)$. Conclusão - Nossos resultados sugerem uma possível implicação do polimorfismo da região promotora -607 do gene IL-18 na patogenia da infecção pelo vírus da hepatite $C$.

DESCRITORES - Polimorfismo de nucleotídeo único. Interleucina-18. Hepatite C. Hepacivirus. 


\section{REFERENCES}

1. An P, Thio CL, Kirk GD, Donfield S, Goedert JJ, Winkler CA. Regulatory polymorphisms in the interleukin-18 promoter are associated with hepatitis $\mathrm{C}$ virus clearance. J Infect Dis. 2008;198(8):1159-65.

2. Arimitsu J, Hirano T, Higa S, Kawai M, Naka T, Ogata A, et al. IL-18 gene polymorphisms affect IL-18 production capability by monocytes. Biochem Biophys Res Commun. 2006;342(4):1413-6.

3. Asselah T, Estrabaud E, Bieche I, Lapalus M, De Muynck S, Vidaud M, et al. Hepatitis C: viral and host factors associated with non-response to pegylated interferon plus ribavirin. Liver Int. 2010;30(9):1259-69.

4. Ayres M, Ayres Junior M, Ayres DM, Dos Santos AS. Bio Estat 5.0: aplicações estatísticas das ciências biológicas e médicas, 5. ed. Belém: Sociedade Civil Mamirauá. MCTCNPq, 2007.

5. Baldick CJ, Wichroski MJ, Pendri A, Walsh AW, Fang J, Mazzucco CE, et al. A novel small lmolecule inibhitor of hepatitis C vírus entry. PLoS Pathog. 2010;6(9):e1001086.

6. Bouzgarrou N, Hassen E, Schvoerer E, Stool-Keller F, Bahri O, Gabbouj S, et al. Association of Interleukin-18 polymorphisms and plasma level with the outcome of chronic HCV infection. J Med Virol. 2008;80(40):607-14.

7. Campiotto S, Pinho JRR, Carrilho FJ, Da Silva LC, Souto FJD, Spinelli V, et al. Geographic distribution of hepatitis $\mathrm{C}$ vírus genotypes in Brazil. Braz J Med Biol Res. 2005;38(1):41-9.

8. Castello G1, Scala S, Palmieri G, Curley SA, Izzo F. HCV-related hepatocellular carcinoma: from chronic inflammation to cancer. Clin Immunol. 2010;134(3): 237-50.

9. Giedraitis V, He B, Huang W-X, Hillert J. Cloning and mutation analysis of the human IL-18 promoter: a possible role of polymorphisms in expression regulation. J Neuroimmunol. 2001;112(1-2):146-52.

10. Haas SL, Weiss C, Bugert $\mathrm{P}$, Gundt J, Witt H, Singer MV, et al. Interleukin 18 promoter variants $(-137 \mathrm{G}>\mathrm{C}$ and $-607 \mathrm{C}>\mathrm{A})$ in patients with chronic hepatitis C: association with treatment response. J Clin Immunol. 2009;29(5):620-8.

11. Hazari S, Acharya SK, Panda SK. Development and evaluation of a quantitative competitive reverse transcription polymerase chain reaction (RT-PCR) for hepatitis $\mathrm{C}$ virus RNA in serum using transcribed thio-RNA as internal control. J Virol Methods. 2004;116(1):45-54
12. Manohar K, Suneetha PV, Sukriti Pati NT, Gupta AC, Hissar S, Sakhuja P, Sarin SK. Associationof IL-18 promoter polymorphism with liver disease severity in HCV-infected patients. Hepatology International. 2009;3(2):371-7.

13. Mihm S, Fayyazi A, Hartmann H, Ramadori G. Analysis of histopathological manifestations of chronic hepatitis $\mathrm{C}$ virus infection with respect to virus genotype. Hepatology. 1997;25(3):735-9.

14. Morales RJP, Rodriguez TRV, Torres O, Morado IC, Castañeda S, Filloy JAM, et al. Association between IL-18 gene polymorphisms and biopsy-proven giant cell arteritis. Arthritis Res Ther. 2010;12(2):1-7.

15. Nousbaum J-B, Pol S, Nalpas B, Landais P, Berthelot P, Brechot C. Hepatitis C virus type 1b (II) infection in France and Italy. Ann Intern Med. 1995;122(3):161-8.

16. Oliveira CSF de, Silva AV, Santos KN, Fecury AA, Almeida MKC de, Fernades AP, et al. Hepatitis B and $\mathrm{C}$ virus infection among Brazilian Amazon riparians. Rev Soc Bras Med Trop. 2011;44(5):546-50.

17. Puoti C, Guarisco R, Bellis L, Spilabotti L. Diagnosis, management, and treatment of hepatitis C. Hepatology. 2009;50(1):322.

18. Sawada L, Pinheiro AC, Locks D, Pimenta A do S, Rezende PR, et al. Distribution of hepatitis $\mathrm{C}$ virus genotypes among different exposure categories in the State of Pará, Brazilian Amazon. Rev Soc Med Trop. 2011;44(1):8-12.

19. Shin HD, Kim LH, Park BL, Choi YH, Park HS, Hong SJ, et al. Association of interleukin 18 (IL18) polymorphisms with specific IgE levels to mite allergens among asthmatic patients. Allergy. 2005;60(7):900-6.

20. Singh S, Gupta R, Malhotra V, Sarin SK. Predictors of histological activity and fibrosis in chronic hepatitis $\mathrm{C}$ infection: a study from North India. Ind $\mathrm{J}$ Pathol Microbiol. 2010;53(2):238-43.

21. Tomanovic NR, Boricic IV, Brasanac DC, Stojsic ZM, Delic DS, Brmbolic BJ Activated liver stellate cells in chronic viral $\mathrm{C}$ hepatitis: histopathological and immunohistochemical study. Journal Gastrointestinal Liver Diseases. 2009;18(2): 163-7.

22. Viso ATR, Barbosa TC, Yamamoto L, Pagliari C, Fernandes ER, Brasil RA, Andrade Junior HF, Duarte MIS, Barone AA. Portal CD4+ and CD8+ T lymphocyte correlate to intensity of interface hepatitis in chronic hepatitis $\mathrm{C}$. Rev Inst Med trop S Paulo, 2007;49(6):371-8.

23. Yue M, Wang J, Tang S, Feng L, Zhang Y, Liu Y, et al. Association of interleukin-18 gene polymorphisms with the outcomes of hepatitis $\mathrm{C}$ virus infection in high-risk Chinese Han population. Immunol Lett. 2013;154(1-2):54-60. 